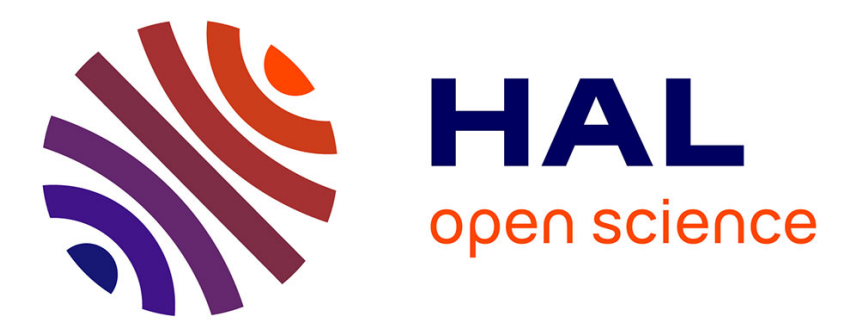

\title{
Metal(loid)s in superficial sediments from coral reefs of French Polynesia
}

Marc Besson, Marc Metian, Paco Bustamante, Laetitia Hédouin

\section{To cite this version:}

Marc Besson, Marc Metian, Paco Bustamante, Laetitia Hédouin. Metal(loid)s in superficial sediments from coral reefs of French Polynesia. Marine Pollution Bulletin, 2020, 155, pp.111175. 10.1016/j.marpolbul.2020.111175 . hal-02563742

\section{HAL Id: hal-02563742 \\ https://hal.science/hal-02563742}

Submitted on 5 May 2020

HAL is a multi-disciplinary open access archive for the deposit and dissemination of scientific research documents, whether they are published or not. The documents may come from teaching and research institutions in France or abroad, or from public or private research centers.
L'archive ouverte pluridisciplinaire $\mathbf{H A L}$, est destinée au dépôt et à la diffusion de documents scientifiques de niveau recherche, publiés ou non, émanant des établissements d'enseignement et de recherche français ou étrangers, des laboratoires publics ou privés. 


\section{Metal(loid)s in superficial sediments from coral reefs of French Polynesia}

Marc Besson ${ }^{1 *}$, Marc Metian$^{1}$, Paco Bustamante ${ }^{2,3}$, Laetitia Hédouin $^{4,5}$

${ }^{1}$ Environment Laboratories, International Atomic Energy Agency, 98000 Principality of Monaco, Monaco; ${ }^{2}$ Littoral Environnement et Sociétés (LIENSs), UMR 7266, CNRS - La Rochelle Université, 17000 La Rochelle, France ; ${ }^{3}$ Institut Universitaire de France (IUF), 1 rue Descartes 75005 Paris, France $;{ }^{4}$ PSL Research University: EPHEUPVD-CNRS, USR 3278 CRIOBE, 98729 Mo'orea, French Polynesia; ${ }^{5}$ Laboratoire d'Excellence Corail, BP1013, Papetoai, Mo’orea, Polynésie française.

* Correspondence to: Marc Besson; Radioecology Laboratory, IAEA, 4a Quai Antoine 1er, 98000 Monaco; Tel: +377.97.97.72.17; Email: marc.besson@ens-lyon.org.

Abstract: French Polynesia exhibit a wide diversity of islands and coral-reef habitats, from urbanized high islands to remote atolls. Here, we present a geographically extensive baseline survey that examine the levels of nine metals $(\mathrm{Ag}, \mathrm{Cd}, \mathrm{Co}, \mathrm{Cu}, \mathrm{Fe}, \mathrm{Mn}, \mathrm{Ni}, \mathrm{Pb}$ and $\mathrm{Zn})$ and one metalloid (As) in superficial sediments from 28 sites spread over three islands of French Polynesia. We used Principal Component Analysis, Pearson's correlation, hierarchical cluster analysis and generalized linear mixed-effect models on Pollution Load Index to investigate site contamination and metal(loid) associations. At most sites, metal(loid) levels below commonly applied sediment quality guidelines. However, a few sites located near farming activities, river discharges and urbanized areas showed contamination levels above these guidelines. This study provides critical baseline values for metal(loid) contaminants in this region and in coral-reef areas in general, and spur decreased discharge of metal(loid) contaminants in the anthropogenised areas of French Polynesia.

Keywords: Contamination; metals; metalloids; Pacific Ocean; South Pacific Islands 
Marine ecosystems have been experiencing increasingly frequent and severe environmental impacts due to growing anthropogenic activities (Halpern et al., 2008). Among these stressors, metal and metalloid - named metal(loid) - pollution has been recognized as an important threat to marine ecosystems for at least 40 years (Chapman et al., 2006; Stoeppler and Nürnberg, 1979). Global stressors (e.g. increasing seawater temperature and ocean acidification) can increase the toxicity of such chemical pollutant towards marine organisms (Noyes et al., 2009), and, in turn, such toxicants can reduce the resistance and resilience of marine organisms to global stressors (Negri et al., 2011; Negri and Hoogenboom, 2011). Metal(loid) pollution may therefore alter the ability of organisms to cope with climate change, and vice-versa. While global stressors are difficult to manage, efficient local management actions to reduce metal(loid) pollution may enhance the resistance of marine organisms to current and predicted environmental conditions. However, this requires baseline information on the levels of metal(loid) contamination in marine ecosystems. Sediments are good indicators of pollution history as they are major sinks of metal(loid)s following their discharge in the environment, whether the sources are natural or anthropogenic (Rodriguez-Barroso et al., 2010).

Coral reefs in tropical areas suffer increasing development of human activities that results in metal(loid) discharges in coastal areas (van Dam et al., 2011). Data related to metal(loid) contamination in sediments from coral reef areas have focused on a few regions such as Australia (Haynes and Johnson, 2000; Reichelt and Jones, 1994), Caribbean and Central America (Gibbs and Guerra, 1997; Guzmán and Jiménez, 1992), Guam (Denton et al., 2005), Hawaii (Hédouin et al., 2009b, 2011a), New Caledonia (Hédouin et al., 2011b, 2009a; Metian et al., 2008), Fiji (Morrison et al., 2001), Samoa (Morrison et al., 2010) and Venezuela (Bastidas et al., 1999). 
However, such data is limited in French Polynesia, a region as vast as Europe in the South Pacific Ocean and composed of 118 islands with a wide diversity of island types from high islands (e.g. Tahiti and Mo'orea, Society archipelago) to atolls (e.g. Rangiroa, Tuamotu archipelago) (ORSTOM, 1993). Metal(loid) levels in the sediment were only investigated through two single cores performed at two sites in Tahiti, within the harbor of Papeete (Fichez et al., 2005). Moreover, while organic and metal(loid) contamination have also been examined in coral reef organisms at Mo'orea (Fey et al., 2019; Roche et al., 2011), data related to the sediment are actually limited to the sedimentary organic matter at a single site (Fey et al., 2019). The current lack of information on the metal(loid) levels in the sediments of French Polynesia coral reefs represents significant hurdles to determine whether the increasing development of anthropogenic activities in this region (Thiault et al., 2018) is associated with an increased contamination in metal(loid)s.

In this context, we measured the levels of ten metal(loid)s (Ag, $\mathrm{As}, \mathrm{Cd}, \mathrm{Co}, \mathrm{Cu}, \mathrm{Fe}, \mathrm{Mn}, \mathrm{Ni}, \mathrm{Pb}$, and $\mathrm{Zn}$ ) in superficial sediments from 28 sites spread over the coral reefs of three contrasted islands of French Polynesia (Mo'orea, Rangiroa and Tahiti; Fig. 1). Tahiti is the most populated island of French Polynesia with 189,517 inhabitants (Insee/Ispf, 2017). It is located in the Society Archipelago and has two parts: a main island called Tahiti Nui and a peninsula called Tahiti Iti. Industrial activities are mainly located in the vicinity of the capital (Papeete) on Tahiti nui. Most of the population also inhabit Tahiti nui (89\%, Insee/Ispf, 2017). Nonetheless, it has developed rapidly in the recent years, and predominantly associated with the construction of several goods and services establishments at Taravao (Tahiti Iti main city). Mo'orea is also located in the Society Archipelago, $17 \mathrm{~km}$ northwest of Tahiti. It is the second most urbanized island of French Polynesia, with 17,816 inhabitants (Insee/Ispf, 2017). Mo'orea is far less industrialized than Tahiti, restricted 
to some intensive agriculture activities (e.g. pineapple production), a fruit juice processing factory and most of the boat traffic related to ferries and daily transfers from Papeete to Vaiare harbor. Rangiroa is the largest atoll of French Polynesia, located in the Tuamotu Archipelago at approximately $430 \mathrm{~km}$ northeast of Papeete. There is no industry on the island and limited anthropogenic activities (i.e. pearl production, fishing, and tourism, all operating on a small scale) with 3,657 inhabitants (Insee/Ispf, 2017).

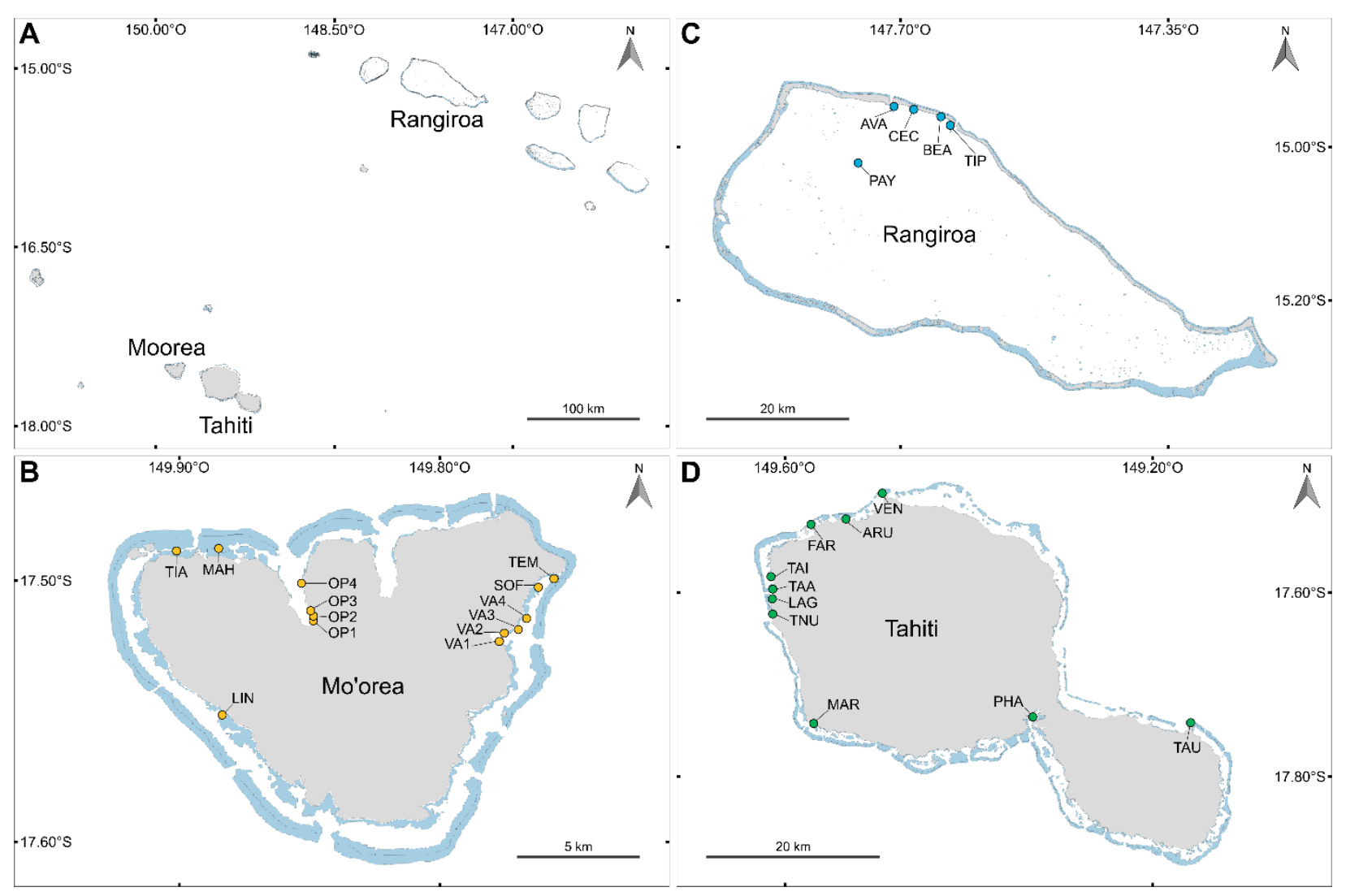

Figure 1. Location of the sampling sites in Mo'orea, Rangiroa and Tahiti. A: Location of the three islands in French Polynesia. B-D: Location of the sampling sites in Mo'orea, Rangiroa and Tahiti, respectively. Gray zones indicate land areas and blue zones indicate coral reef areas. Site codes used in the other figures and tables of this manuscript correspond to the island initial followed by the site names presented in B-D.

Sampling sites were selected along the coasts of Tahiti (10 sites), Mo'orea (13 sites) and Rangiroa (5 sites) (Fig. 1), by choosing sites with various anthropogenic inputs, i.e. potentially contaminated 
sites near the river mouth in the vicinity of cities, industries, harbors and marinas, and suitable reference sites close to remote beaches and reefs supposedly less contaminated (Table S1). Sediment samples were collected from September to November 2012. At each site, three superficial sediment samples (i.e. triplicates), each of 50 to $75 \mathrm{~g}$ wet weight (ww), were collected in acid-washed plastic bags by scuba diving. Following collection, samples were stored in a freezer at $-20^{\circ} \mathrm{C}$ until being processed for contaminant analyses. Before analysis, each sample was screened through a $1 \mathrm{~mm}$ sieve to remove large particles (this < $1 \mathrm{~mm}$ fraction constitutes $80-90 \%$ of the total sediment of each sample, and preliminary observations showed that the $<63 \mathrm{~mm}$ fraction represented less than $0.2 \%$ of the total sediment). Aliquots of $150-250 \mathrm{mg}$ were microwave digested in a mixture of $3 \mathrm{ml}$ of suprapure nitric acid (VWR/Merck) and $1 \mathrm{ml}$ of suprapure hydrochloric acid (VWR/Merck), and then diluted to $25 \mathrm{ml}$ with MilliQ-quality water. Metal(oid)s were then analyzed by Inductively Coupled Plasma Atomic Emission Spectrometry (Varian VistaPro ICP-OES) and Mass Spectrometry (ThermoFisherScientific XSeries II ICP-MS). Certified Reference Materials (CRM) provided by the National Research Council Canada were treated and analyzed in a similar way as the samples. The CRM were dogfish liver DOLT-4, lobster hepatopancreas TORT-2 and marine sediment MESS-3 and the results from their analysis indicated a recovery ranging from 80 to $107 \%$ (Table S2).

The concentrations of metal(loid)s measured in superficial sediments from 28 sites in French Polynesia coral reefs ranged from 0.01 to $1.18 \mu \mathrm{g} \mathrm{g}^{-1} \mathrm{dw}$ (dry weight) for Ag, 0.21 to $27.3 \mu \mathrm{g} \mathrm{g}^{-1}$ $\mathrm{dw}$ for As, 0.01 to $0.20 \mu \mathrm{g} \mathrm{g}^{-1} \mathrm{dw}$ for Cd, 0.46 to $42.2 \mu \mathrm{g} \mathrm{g}^{-1} \mathrm{dw}$ for Co, 0.14 to $35.1 \mu \mathrm{g} \mathrm{g}^{-1} \mathrm{dw}$ for $\mathrm{Cu}, 10.4$ to $32,513 \mu \mathrm{g} \mathrm{g}^{-1} \mathrm{dw}$ for Fe, 0.11 to $549 \mu \mathrm{g} \mathrm{g}^{-1} \mathrm{dw}$ for Mn, 0.04 to $325 \mu \mathrm{g} \mathrm{g}^{-1} \mathrm{dw}$ for $\mathrm{Ni}$, 0.02 to $21.5 \mu \mathrm{g} \mathrm{g}^{-1} \mathrm{dw}$ for $\mathrm{Pb}$ and 3.03 to $194 \mu \mathrm{g} \mathrm{g}^{-1} \mathrm{dw}$ for $\mathrm{Zn}$ (Table 1). 
Table 1. Metal(loid) concentrations in superficial sediments from coral reefs of French Polynesia. Data are expressed in $\mu \mathrm{g} \mathrm{g}^{-1} \mathrm{dw}$ (dry weight), and correspond to the mean (sd) of $\mathrm{n}=3$ samples for each site (i.e. triplicates). $\S$ indicates sd $<0.005$. Sites are indicated by the initial of the island, followed by the site name as in Fig. 1.

\begin{tabular}{|c|c|c|c|c|c|c|c|c|c|c|}
\hline Site & Ag & As & Cd & Co & $\mathrm{Cu}$ & $\mathbf{F e}$ & Mn & $\mathbf{N i}$ & $\mathbf{P b}$ & $\mathbf{Z n}$ \\
\hline M-LIN & $\begin{array}{c}0.03 \\
(\S)\end{array}$ & $\begin{array}{c}1.43 \\
(0.11)\end{array}$ & $\begin{array}{c}0.02 \\
(\S)\end{array}$ & $\begin{array}{c}3.91 \\
(0.12)\end{array}$ & $\begin{array}{c}0.40 \\
(0.02)\end{array}$ & $\begin{array}{c}550 \\
(19.8)\end{array}$ & $\begin{array}{c}8.81 \\
(0.90)\end{array}$ & $\begin{array}{c}0.81 \\
(0.12)\end{array}$ & $\begin{array}{c}0.18 \\
(0.01)\end{array}$ & $\begin{array}{c}4.43 \\
(0.11)\end{array}$ \\
\hline M-MAH & $\begin{array}{c}0.11 \\
(\S)\end{array}$ & $\begin{array}{c}0.22 \\
(0.01)\end{array}$ & $\begin{array}{c}0.02 \\
(\S)\end{array}$ & $\begin{array}{c}18.4 \\
(0.66)\end{array}$ & $\begin{array}{c}0.39 \\
(0.03)\end{array}$ & $\begin{array}{c}109 \\
(3.19)\end{array}$ & $\begin{array}{c}5.35 \\
(0.79)\end{array}$ & $\begin{array}{c}0.04 \\
(0.01)\end{array}$ & $\begin{array}{c}0.03 \\
(0.01)\end{array}$ & $\begin{array}{c}4.52 \\
(0.06)\end{array}$ \\
\hline M-OPU1 & $\begin{array}{c}1.18 \\
(0.10)\end{array}$ & $\begin{array}{c}16.2 \\
(0.12)\end{array}$ & $\begin{array}{c}0.20 \\
(0.02)\end{array}$ & $\begin{array}{c}14.6 \\
(0.74)\end{array}$ & $\begin{array}{c}31.7 \\
(17.4)\end{array}$ & $\begin{array}{l}28585 \\
(1157)\end{array}$ & $\begin{array}{c}512 \\
(23.8)\end{array}$ & $\begin{array}{c}62.6 \\
(3.57)\end{array}$ & $\begin{array}{c}2.01 \\
(0.09)\end{array}$ & $\begin{array}{c}60.6 \\
(5.64)\end{array}$ \\
\hline M-OPU2 & $\begin{array}{c}0.48 \\
(0.04)\end{array}$ & $\begin{array}{c}7.87 \\
(1.42)\end{array}$ & $\begin{array}{c}0.08 \\
(0.01)\end{array}$ & $\begin{array}{c}5.95 \\
(0.86)\end{array}$ & $\begin{array}{c}14.2 \\
(0.24)\end{array}$ & $\begin{array}{c}32513 \\
(765)\end{array}$ & $\begin{array}{c}549 \\
(13.8)\end{array}$ & $\begin{array}{c}68.9 \\
(2.35)\end{array}$ & $\begin{array}{c}0.91 \\
(0.15)\end{array}$ & $\begin{array}{c}77.3 \\
(4.91)\end{array}$ \\
\hline M-OPU3 & $\begin{array}{c}0.15 \\
(\S)\end{array}$ & $\begin{array}{c}2.48 \\
(0.15)\end{array}$ & $\begin{array}{c}0.04 \\
(0.02)\end{array}$ & $\begin{array}{c}14.7 \\
(0.25)\end{array}$ & $\begin{array}{c}0.92 \\
(0.12)\end{array}$ & $\begin{array}{l}2163 \\
(171)\end{array}$ & $\begin{array}{l}28.0 \\
(2.84)\end{array}$ & $\begin{array}{c}2.30 \\
(0.63)\end{array}$ & $\begin{array}{c}0.45 \\
(0.08)\end{array}$ & $\begin{array}{c}5.79 \\
(1.15)\end{array}$ \\
\hline M-OPU4 & $\begin{array}{c}0.12 \\
(0.01)\end{array}$ & $\begin{array}{c}2.95 \\
(0.36)\end{array}$ & $\begin{array}{c}0.02 \\
(\S)\end{array}$ & $\begin{array}{c}12.3 \\
(0.73)\end{array}$ & $\begin{array}{c}0.56 \\
(0.01)\end{array}$ & $\begin{array}{l}2007 \\
(145)\end{array}$ & $\begin{array}{c}49.9 \\
(2.67)\end{array}$ & $\begin{array}{c}2.50 \\
(0.60)\end{array}$ & $\begin{array}{c}0.92 \\
(0.10)\end{array}$ & $\begin{array}{c}4.61 \\
(0.53)\end{array}$ \\
\hline M-SOF & $\begin{array}{c}0.03 \\
(\S)\end{array}$ & $\begin{array}{c}0.81 \\
(0.02)\end{array}$ & $\begin{array}{c}0.02 \\
(0.01)\end{array}$ & $\begin{array}{c}3.81 \\
(0.05)\end{array}$ & $\begin{array}{c}0.23 \\
(0.01)\end{array}$ & $\begin{array}{c}236 \\
(20.2)\end{array}$ & $\begin{array}{c}2.65 \\
(0.18)\end{array}$ & $\begin{array}{c}0.17 \\
(0.14)\end{array}$ & $\begin{array}{c}1.17 \\
(1.04)\end{array}$ & $\begin{array}{c}4.42 \\
(0.13)\end{array}$ \\
\hline M-TEM & $\begin{array}{l}0.02 \\
(\S)\end{array}$ & $\begin{array}{c}0.56 \\
(0.03)\end{array}$ & $\begin{array}{c}0.04 \\
(0.02)\end{array}$ & $\begin{array}{c}3.97 \\
(0.05)\end{array}$ & $\begin{array}{l}0.25 \\
(\S)\end{array}$ & $\begin{array}{c}55.1 \\
(5.29)\end{array}$ & $\begin{array}{c}2.09 \\
(0.19)\end{array}$ & $\begin{array}{c}0.06 \\
(0.03)\end{array}$ & $\begin{array}{c}0.17 \\
(0.01)\end{array}$ & $\begin{array}{c}4.23 \\
(0.21)\end{array}$ \\
\hline M-TIA & $\begin{array}{c}0.01 \\
(0.01)\end{array}$ & $\begin{array}{c}7.58 \\
(0.34)\end{array}$ & $\begin{array}{c}0.01 \\
(0.01)\end{array}$ & $\begin{array}{c}0.47 \\
(0.02)\end{array}$ & $\begin{array}{c}0.76 \\
(0.03)\end{array}$ & $\begin{array}{c}197 \\
(13.1)\end{array}$ & $\begin{array}{c}4.55 \\
(0.38)\end{array}$ & $\begin{array}{c}1.51 \\
(0.07)\end{array}$ & $\begin{array}{c}3.03 \\
(0.14)\end{array}$ & $\begin{array}{c}3.03 \\
(0.14)\end{array}$ \\
\hline M-VAI1 & $\begin{array}{c}0.21 \\
(0.02)\end{array}$ & $\begin{array}{c}17.8 \\
(2.03)\end{array}$ & $\begin{array}{c}0.07 \\
(0.01)\end{array}$ & $\begin{array}{c}4.48 \\
(0.13)\end{array}$ & $\begin{array}{c}1.89 \\
(0.41)\end{array}$ & $\begin{array}{l}6727 \\
(531)\end{array}$ & $\begin{array}{c}97.8 \\
(5.09)\end{array}$ & $\begin{array}{c}6.98 \\
(0.72)\end{array}$ & $\begin{array}{c}0.89 \\
(0.10)\end{array}$ & $\begin{array}{c}14.7 \\
(1.43)\end{array}$ \\
\hline M-VAI2 & $\begin{array}{c}0.09 \\
(0.02)\end{array}$ & $\begin{array}{c}12.3 \\
(0.66)\end{array}$ & $\begin{array}{c}0.03 \\
(0.01)\end{array}$ & $\begin{array}{c}2.34 \\
(0.52)\end{array}$ & $\begin{array}{c}4.80 \\
(0.54)\end{array}$ & $\begin{array}{l}5688 \\
(756)\end{array}$ & $\begin{array}{c}83.7 \\
(2.84)\end{array}$ & $\begin{array}{c}8.24 \\
(1.37)\end{array}$ & $\begin{array}{c}3.28 \\
(0.04)\end{array}$ & $\begin{array}{c}18.6 \\
(2.73)\end{array}$ \\
\hline M-VAI3 & $\begin{array}{c}0.02 \\
(\S)\end{array}$ & $\begin{array}{c}8.00 \\
(0.17)\end{array}$ & $\begin{array}{c}0.02 \\
(\S)\end{array}$ & $\begin{array}{c}0.53 \\
(\S)\end{array}$ & $\begin{array}{c}0.80 \\
(0.02)\end{array}$ & $\begin{array}{c}1233 \\
(70.1)\end{array}$ & $\begin{array}{c}31.1 \\
(1.52)\end{array}$ & $\begin{array}{c}2.21 \\
(0.28)\end{array}$ & $\begin{array}{c}3.20 \\
(0.07)\end{array}$ & $\begin{array}{c}3.20 \\
(0.07)\end{array}$ \\
\hline M-VAI4 & $\begin{array}{c}0.02 \\
(0.01)\end{array}$ & $\begin{array}{c}7.88 \\
(0.45)\end{array}$ & $\begin{array}{c}0.02 \\
(0.01)\end{array}$ & $\begin{array}{c}0.50 \\
(0.01)\end{array}$ & $\begin{array}{c}0.79 \\
(0.04)\end{array}$ & $\begin{array}{c}518 \\
(153)\end{array}$ & $\begin{array}{c}8.06 \\
(1.72)\end{array}$ & $\begin{array}{c}1.67 \\
(0.08)\end{array}$ & $\begin{array}{c}3.15 \\
(0.18)\end{array}$ & $\begin{array}{c}3.15 \\
(0.18)\end{array}$ \\
\hline R-AVA & $\begin{array}{c}0.03 \\
(\S)\end{array}$ & $\begin{array}{c}0.38 \\
(0.10)\end{array}$ & $\begin{array}{c}0.02 \\
(\S)\end{array}$ & $\begin{array}{c}5.39 \\
(0.10)\end{array}$ & $\begin{array}{c}0.28 \\
(0.01)\end{array}$ & $\begin{array}{c}82.2 \\
(36.7)\end{array}$ & $\begin{array}{c}0.82 \\
(0.09)\end{array}$ & $\begin{array}{c}0.04 \\
(0.01)\end{array}$ & $\begin{array}{c}0.45 \\
(0.07)\end{array}$ & $\begin{array}{c}4.19 \\
(0.16)\end{array}$ \\
\hline R-BEA & $\begin{array}{l}0.03 \\
(\S)\end{array}$ & $\begin{array}{c}0.59 \\
(0.13)\end{array}$ & $\begin{array}{c}0.04 \\
(0.02)\end{array}$ & $\begin{array}{c}5.24 \\
(0.08)\end{array}$ & $\begin{array}{c}0.25 \\
(0.01)\end{array}$ & $\begin{array}{c}12.8 \\
(4.86)\end{array}$ & $\begin{array}{c}0.54 \\
(0.09)\end{array}$ & $\begin{array}{c}0.07 \\
(0.04)\end{array}$ & $\begin{array}{c}0.14 \\
(0.01)\end{array}$ & $\begin{array}{c}5.00 \\
(1.58)\end{array}$ \\
\hline R-CEC & $\begin{array}{c}0.02 \\
(\S)\end{array}$ & $\begin{array}{c}0.68 \\
(0.08)\end{array}$ & $\begin{array}{c}0.02 \\
(\S)\end{array}$ & $\begin{array}{c}4.01 \\
(0.05)\end{array}$ & $\begin{array}{c}0.21 \\
(\S)\end{array}$ & $\begin{array}{c}90.3 \\
(24.5)\end{array}$ & $\begin{array}{c}1.30 \\
(0.20)\end{array}$ & $\begin{array}{c}0.04 \\
(\S)\end{array}$ & $\begin{array}{c}0.13 \\
(0.01)\end{array}$ & $\begin{array}{c}4.32 \\
(0.07)\end{array}$ \\
\hline R-PAY & $\begin{array}{c}0.03 \\
(\S)\end{array}$ & $\begin{array}{c}0.21 \\
(0.02)\end{array}$ & $\begin{array}{l}0.02 \\
(\S)\end{array}$ & $\begin{array}{c}5.31 \\
(0.05)\end{array}$ & $\begin{array}{c}0.17 \\
(0.02)\end{array}$ & $\begin{array}{c}31.8 \\
(48.0)\end{array}$ & $\begin{array}{c}0.30 \\
(0.29)\end{array}$ & $\begin{array}{c}0.04 \\
(\S)\end{array}$ & $\begin{array}{c}0.02 \\
(\S)\end{array}$ & $\begin{array}{c}4.17 \\
(0.41)\end{array}$ \\
\hline R-TIP & $\begin{array}{c}0.03 \\
(\S)\end{array}$ & $\begin{array}{c}0.23 \\
(0.01)\end{array}$ & $\begin{array}{c}0.02 \\
(\S)\end{array}$ & $\begin{array}{c}5.05 \\
(0.14)\end{array}$ & $\begin{array}{c}0.14 \\
(0.01)\end{array}$ & $\begin{array}{c}10.4 \\
(0.29)\end{array}$ & $\begin{array}{c}0.11 \\
(\S)\end{array}$ & $\begin{array}{c}0.05 \\
(0.01)\end{array}$ & $\begin{array}{c}0.03 \\
(0.01)\end{array}$ & $\begin{array}{c}4.51 \\
(0.03)\end{array}$ \\
\hline T-ARU & $\begin{array}{c}0.03 \\
(0.01)\end{array}$ & $\begin{array}{c}8.30 \\
(0.08)\end{array}$ & $\begin{array}{c}0.02 \\
(\S)\end{array}$ & $\begin{array}{c}3.35 \\
(0.25)\end{array}$ & $\begin{array}{c}1.62 \\
(0.25)\end{array}$ & $\begin{array}{l}4648 \\
(342)\end{array}$ & $\begin{array}{c}57.9 \\
(0.46)\end{array}$ & $\begin{array}{c}12.4 \\
(1.02)\end{array}$ & $\begin{array}{c}3.29 \\
(0.08)\end{array}$ & $\begin{array}{c}8.53 \\
(0.66)\end{array}$ \\
\hline T-FAR & $\begin{array}{c}0.06 \\
(0.01)\end{array}$ & $\begin{array}{c}8.07 \\
(0.55)\end{array}$ & $\begin{array}{c}0.06 \\
(0.04)\end{array}$ & $\begin{array}{c}20.8 \\
(1.40)\end{array}$ & $\begin{array}{c}35.1 \\
(8.60)\end{array}$ & $\begin{array}{l}20191 \\
(1141)\end{array}$ & $\begin{array}{c}286 \\
(19.4)\end{array}$ & $\begin{array}{c}118 \\
(10.5)\end{array}$ & $\begin{array}{c}21.5 \\
(11.8)\end{array}$ & $\begin{array}{c}194 \\
(112)\end{array}$ \\
\hline T-LAG & $\begin{array}{c}0.05 \\
(0.01)\end{array}$ & $\begin{array}{c}8.45 \\
(0.99)\end{array}$ & $\begin{array}{c}0.02 \\
(0.01)\end{array}$ & $\begin{array}{c}20.8 \\
(3.60)\end{array}$ & $\begin{array}{c}11.4 \\
(1.24)\end{array}$ & $\begin{array}{l}18820 \\
(1782)\end{array}$ & $\begin{array}{c}227 \\
(30.9)\end{array}$ & $\begin{array}{c}107 \\
(24.8)\end{array}$ & $\begin{array}{c}3.31 \\
(0.18)\end{array}$ & $\begin{array}{c}40.7 \\
(7.98)\end{array}$ \\
\hline T-MAR & $\begin{array}{c}0.02 \\
(\S)\end{array}$ & $\begin{array}{c}8.02 \\
(0.37)\end{array}$ & $\begin{array}{c}0.02 \\
(\S)\end{array}$ & $\begin{array}{c}1.26 \\
(0.30)\end{array}$ & $\begin{array}{c}0.80 \\
(0.04)\end{array}$ & $\begin{array}{l}1797 \\
(145)\end{array}$ & $\begin{array}{c}18.5 \\
(3.46)\end{array}$ & $\begin{array}{c}4.70 \\
(1.57)\end{array}$ & $\begin{array}{c}3.21 \\
(0.15)\end{array}$ & $\begin{array}{c}3.21 \\
(0.15)\end{array}$ \\
\hline T-PHA & $\begin{array}{c}0.03 \\
(0.01)\end{array}$ & $\begin{array}{c}27.3 \\
(1.10)\end{array}$ & $\begin{array}{c}0.02 \\
(\S)\end{array}$ & $\begin{array}{c}5.69 \\
(0.58)\end{array}$ & $\begin{array}{c}1.88 \\
(0.43)\end{array}$ & $\begin{array}{l}7352 \\
(324)\end{array}$ & $\begin{array}{c}130 \\
(21.8)\end{array}$ & $\begin{array}{c}11.4 \\
(1.96)\end{array}$ & $\begin{array}{c}3.21 \\
(0.04)\end{array}$ & $\begin{array}{c}6.81 \\
(0.77)\end{array}$ \\
\hline T-TAA & $\begin{array}{c}0.07 \\
(0.01)\end{array}$ & $\begin{array}{c}8.08 \\
(0.08)\end{array}$ & $\begin{array}{c}0.03 \\
(0.01)\end{array}$ & $\begin{array}{c}18.5 \\
(4.05)\end{array}$ & $\begin{array}{c}22.1 \\
(3.46)\end{array}$ & $\begin{array}{c}16991 \\
(1770)\end{array}$ & $\begin{array}{c}252 \\
(35.7)\end{array}$ & $\begin{array}{c}118 \\
(34.1)\end{array}$ & $\begin{array}{c}3.23 \\
(0.03)\end{array}$ & $\begin{array}{c}28.1 \\
(3.60)\end{array}$ \\
\hline T-TAI & $\begin{array}{c}0.02 \\
(\S)\end{array}$ & $\begin{array}{c}8.21 \\
(0.07)\end{array}$ & $\begin{array}{c}0.02 \\
(\S)\end{array}$ & $\begin{array}{c}0.46 \\
(0.11)\end{array}$ & $\begin{array}{c}0.82 \\
(0.01)\end{array}$ & $\begin{array}{c}955 \\
(411)\end{array}$ & $\begin{array}{c}18.2 \\
(8.64)\end{array}$ & $\begin{array}{c}1.97 \\
(0.28)\end{array}$ & $\begin{array}{c}3.28 \\
(0.03)\end{array}$ & $\begin{array}{c}3.28 \\
(0.03)\end{array}$ \\
\hline T-TAU & $\begin{array}{c}0.02 \\
(\S)\end{array}$ & $\begin{array}{c}8.13 \\
(0.11)\end{array}$ & $\begin{array}{c}0.02 \\
(\S)\end{array}$ & $\begin{array}{c}1.76 \\
(1.35)\end{array}$ & $\begin{array}{c}0.95 \\
(0.25)\end{array}$ & $\begin{array}{c}2427 \\
(1305)\end{array}$ & $\begin{array}{c}29.1 \\
(15.9)\end{array}$ & $\begin{array}{c}8.47 \\
(6.22)\end{array}$ & $\begin{array}{c}3.25 \\
(0.05)\end{array}$ & $\begin{array}{c}4.58 \\
(1.99)\end{array}$ \\
\hline T-TNO & $\begin{array}{l}0.04 \\
(\S)\end{array}$ & $\begin{array}{c}7.98 \\
(0.13)\end{array}$ & $\begin{array}{c}0.02 \\
(\S)\end{array}$ & $\begin{array}{c}42.2 \\
(4.00)\end{array}$ & $\begin{array}{c}6.62 \\
(1.06)\end{array}$ & $\begin{array}{l}25287 \\
(1107)\end{array}$ & $\begin{array}{c}454 \\
(26.6)\end{array}$ & $\begin{array}{c}325 \\
(38.3)\end{array}$ & $\begin{array}{c}5.85 \\
(0.03)\end{array}$ & $\begin{array}{c}50.0 \\
(0.86)\end{array}$ \\
\hline T-VEN & $\begin{array}{l}0.04 \\
(\S)\end{array}$ & $\begin{array}{c}8.25 \\
(0.28)\end{array}$ & $\begin{array}{c}0.02 \\
(\S)\end{array}$ & $\begin{array}{c}27.5 \\
(1.83)\end{array}$ & $\begin{array}{c}8.12 \\
(0.65)\end{array}$ & $\begin{array}{c}21142 \\
(651)\end{array}$ & $\begin{array}{c}308 \\
(16.7)\end{array}$ & $\begin{array}{c}185 \\
(23.6)\end{array}$ & $\begin{array}{c}3.30 \\
(0.11)\end{array}$ & $\begin{array}{c}35.5 \\
(1.01)\end{array}$ \\
\hline
\end{tabular}


Metal(loid) concentrations were then compared to three sediment quality guidelines: the Threshold Effect Level (TEL), the Effect Range Low (ERL), and the Effect Range Median (ERM) (Buchman, 2008; Long et al., 1995), which define concentrations that have adverse effects on biological organisms (Supplementary Text 1). Concentrations were below these sediment quality guidelines for all sites in Rangiroa and most sites in Mo'orea and Tahiti (Fig. S1). In Mo'orea, the sites with metal(loid) concentrations higher than these thresholds were M-OP1 ([Ni] above ERM, [Ag], [As] and [Cu] above ERL), M-OP2 ([Ni] above ERM and [As] above ERL), M-TIA ([As] above TEL) and M-VA1, M-VA2, M-VA3 and M-VA4 ([As] above ERL) (Fig. S1). In Tahiti, all sites showed [As] above ERL and T-FAR, T-LAG, T-TAA, T-TNO and T-VEN exhibited [Ni] above ERM. Also, at T-FAR, $[\mathrm{Cu}]$ and $[\mathrm{Zn}]$ exceeded ERL and [Pb] exceeded TEL (Fig. S1).

Based on the Kaiser criterion (i.e. eigenvalue $\geq 1$, Kaiser, 1960), three principal components (PCs) on metal(loid) levels in sediments were retained, accounted for $86 \%$ of the total variance (Table S3). The Principal Component Analysis (PCA) revealed a largely unidimensional variation in sediment contamination across sites, with PC1 accounting for $55.6 \%$ of the total variance, while PC2 and PC3 accounted for $19.4 \%$ and $12.0 \%$, respectively, of the total variance (Table S3 and loading factors are available in Table S4). PC1 is a good indicator of the overall level of contamination, with a group of almost non-contaminated sediments on the left, and two groups of more contaminated sediments on the right (Fig. 2A). Further cluster analyses confirmed these major groups of sites, with a first group that includes M-OP1, M-OP2, T-FAR, T-LAG, T-TAA, T-TNO and T-VEN, and a second group that includes all the other sites, and in particular all the sites from Rangiroa (Fig. 2B). PC2 and PC3 reflect the differences between Mo'orea and Tahiti in terms of contamination by clustering metal(loid)s in three groups (Fig. 2A and Fig. S2A-B). The 
first group comprises $\mathrm{Ag}$, As and $\mathrm{Cd}$ and drives the contamination in Mo'orea (Fig. 2A). The second group comprises $\mathrm{Cu}, \mathrm{Pb}$ and $\mathrm{Zn}$, and the third group comprises $\mathrm{Co}, \mathrm{Fe}, \mathrm{Mn}$ and $\mathrm{Ni}$, and these groups differ on PC3 (Fig S2A-B) and drive the contamination in Tahiti, in particular at TFAR for the second group. Strong positive ( $r>0.63$, Fig. $2 \mathrm{C}$ ) and significant $(\mathrm{P}<0.001$, Table S5) correlations were indeed observed between $\mathrm{Ag}$ and $\mathrm{Cd}$, between $\mathrm{Cu}, \mathrm{Pb}$ and $\mathrm{Zn}$, and between $\mathrm{Co}$, Fe, Mn and Ni (Fig. 2C, Table S5).

The degree of contamination of the different sites was examined using the Pollution Load Index (PLI) described by Tomlinson et al. (1980). PLI was determined as the $\mathrm{n}^{\text {th }}$ root of the product of the n Contamination Factor $(\mathrm{CF})$ of the n elements: PLI $=\left(\prod_{i}^{n} C F_{i}\right)^{1 / n}$, and $C F_{i}=\frac{C_{i}}{C_{b}}$, where $\mathrm{C}_{\mathrm{i}}$ is the concentration of the metal(loid) $i$, and $C_{b}$ is the background concentration of this metal(loid). Since the concentrations measured in sediments from Rangiroa are lower than those generally used as background values (Bowen, 1979), the means of these concentrations for each metal(loid) were used as background values in the PLI calculations performed in this study. Pollution Load Index (PLI) varied across sites $\left(\chi_{27}^{2}=15617, \mathrm{P}<0.001\right.$; Gamma Generalized Linear Mixed-Effects Model, Supplementary Text 2, Bolker et al., 2009), with the same trends and clusters as in Fig. 2 and Fig. S1. M-OP1, M-OP2 and T-FAR exhibited the highest PLI, followed by T-TAA, T-TNU, T-VEN and T-LAG, and then by M-VA1 and M-VA2 (Fig. 3). Other sites showed a PLI under the average PLI (when combining all sites), and the lowest PLI were observed for sites at Rangiroa (Fig. 3). 

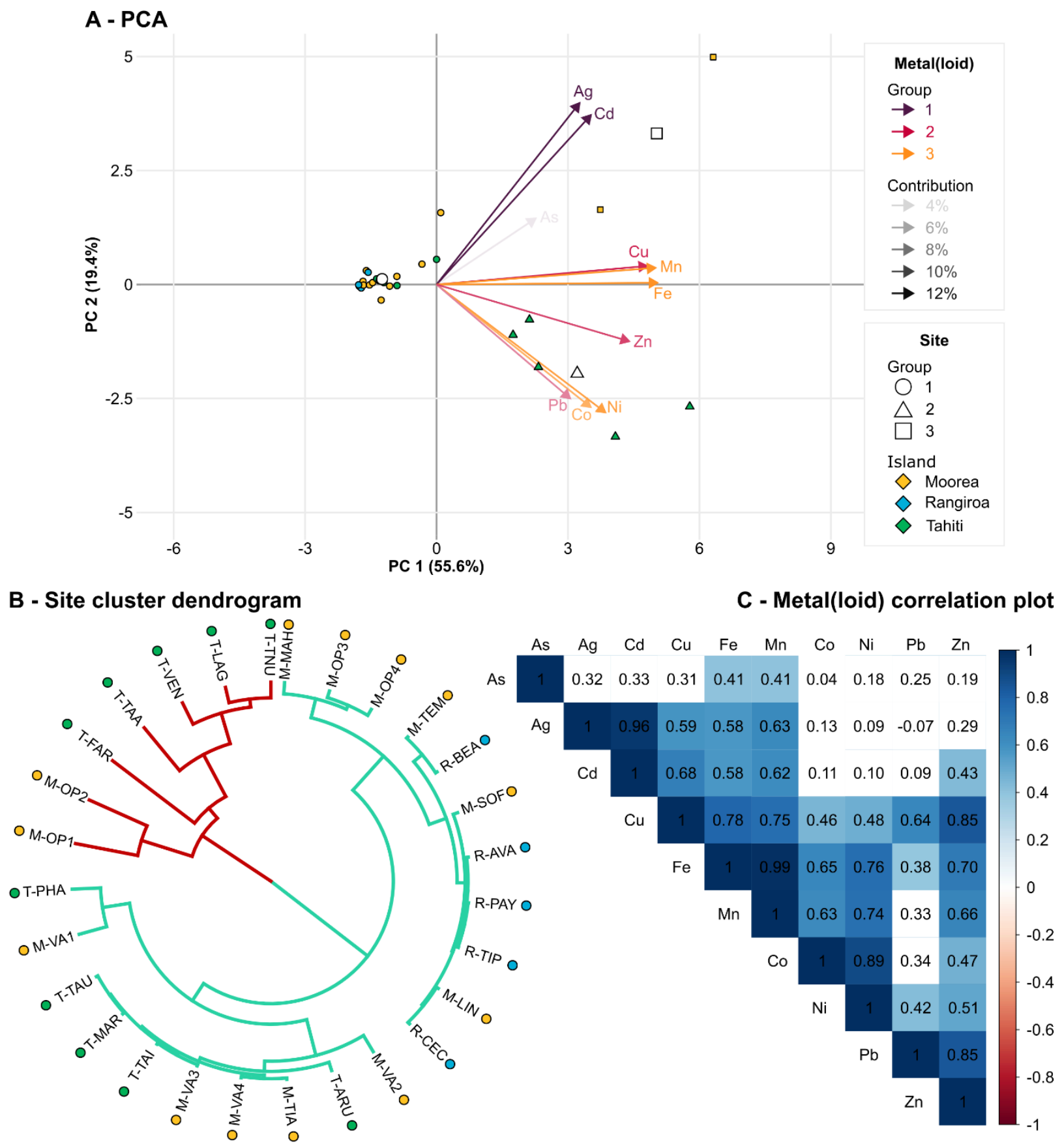

Figure 2. Site and metal(loid) grouping based on the levels measured in the sediment. A: Principal Component Analysis (PCA) of sites (as individuals) and metal(loid)s (as variables) according to metal(loid) concentrations in the 28 sites from Mo'orea, Rangiroa and Tahiti. The three main groups of metal(loid)s and sites have been added. B: Cluster classification of sites based on metal(loid) concentrations. The number of clusters was measured using the gap statistic. Sites are indicated by the initial of the island, followed by the site name as in Fig. 1. C: Correlation plot of metal(loid)s based on their concentrations across sites. Data indicate the Spearman r correlation coefficients. 


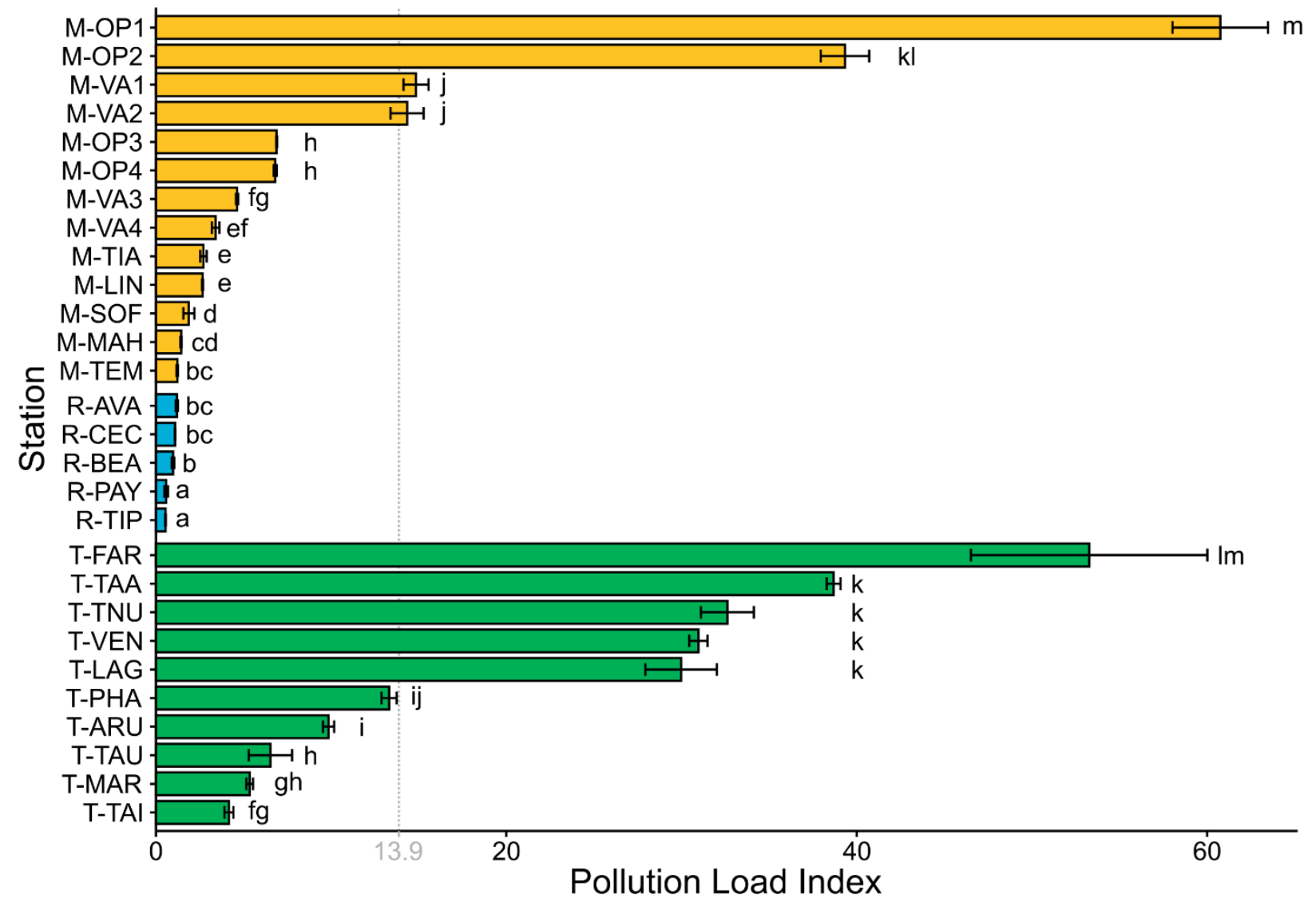

Figure 3. Pollution Load Index (PLI) of reef superficial sediments 28 sites across French Polynesia. Sites from Mo'orea, Rangiroa and Tahiti are indicated by orange, blue and green bars, respectively. Sites are indicated by the initial of the island, followed by the site name as in Fig. 1. Bars and error bars indicate mean $\pm \mathrm{se}(\mathrm{n}=3)$. The dashed line indicates the mean PLI value of all sites. Letters on the right of each bar indicate statistically different groups according to Tukey posthoc-test following Gamma Generalized Linear Mixed-Effect Model.

This study provides the first large-scale baseline of metal(loid) levels in superficial sediments from coral reefs of three islands of French Polynesia, highlighting various degrees of contamination across and within islands. Our results highlight a clear gradient of contamination in metal(loid)s in superficial sediments of French Polynesia, from pristine coral reef sites (e.g. Rangiroa) to sites with higher river discharge and anthropogenic influence (e.g. Mo'orea and Tahiti). In Rangiroa, none of the metal(loid) levels exceeded any of the sediment quality guidelines. These levels were lower than those reported in most other tropical areas (Denton et al., 2005; Morrison et al., 2010), in particular at similar remote and non-polluted sites (Denton et al., 2006, 2005; Denton and 
Morrison, 2009). Further, they are lower than the classically used background values (Bowen, 1979), and therefore represent important baseline values of metal(loid) levels for sediments of French Polynesia but also for coral reef areas in general. Evaluating the levels of metal(loid)s in reef sediments from such remote environments is topical when one wants to assess the environmental effects of anthropogenic activities in more urbanized areas (Kadhum et al., 2015). In Mo'orea, a few sites also exhibited low levels of metal(loid) contamination and similar PLI as Rangiroa sites, while two other sites (M-OP1 and M-OP2, where no coral cover was present) showed the highest PLI of this study. In particular, Ni levels at M-OP1 and M-OP2 exceeded ERM and levels of $\mathrm{Ag}$ and $\mathrm{As}$ exceeded levels recorded in sediments from other coral reef regions (Bastidas et al., 1999; Denton et al., 2005; Guzmán and Jiménez, 1992; Haynes and Johnson, 2000; Hédouin et al., 2011b, 2009b; Metian et al., 2008; Morrison et al., 2010). Sediment contamination rapidly dropped further away in Opunohu Bay, as evidenced by the low levels of contamination recorded at M-OP3 and M-OP4, and the same decreasing contamination gradient was observed in Vaiare Bay (M-VA1 to M-VA4). These gradients are therefore probably linked to the discharge of sediments from the Opunohu and Vaiare streams but also to salinity shifts in Opunohu and Vaiare bays, which are known to affect metal(loid) solubilization, speciation, precipitation, diffusion and advection (Barletta et al., 2019; Coynel et al., 2016; de Souza Machado et al., 2016). In Tahiti, the highest levels of contamination were observed in the sediments collected in Papeete (T-FAR, Table S1), the capital of French Polynesia. This site was the only one monitored in a previous study (Fichez et al., 2005), and we observed moderate increases in the levels of all the elements that examined in both this previous study and the current study. High levels of $\mathrm{Co}, \mathrm{Cu}$, $\mathrm{Fe}, \mathrm{Mn}, \mathrm{Ni}$, and $\mathrm{Zn}$ were observed at 5 sites in Tahiti, with Ni levels exceeding the ERM and constituting a potential threat to marine organisms if bioavailable (Gissi et al., 2016). 
PCA and correlation analyses can highlight which elements may originate from the same source (Yongming et al., 2006), but identifying those sources would require further research and additional data on sediment grain size, total organic carbon content, total nitrogen content, mineralogy, and origin (e.g. terrestrial vs. marine). Indeed, metal(loid) contamination can be influenced by the structure and composition of the sediment itself, as well as by the geological characteristics of the island (Hédouin et al., 2009b). For instance, and in contrast with Rangiroa (Chevalier, 1973), high levels of Fe and Mn are expected in basaltic-rich volcanic islands with high terrestrial inputs such as Mo'orea and Tahiti (Fichez et al., 2005). The overall higher levels of metal(loid)s in the sediments from Tahiti and Mo'orea $v s$. Rangiroa could therefore be related to their river network and higher land surface areas (ORSTOM, 1993). Contamination levels can also be associated with anthropogenic inputs, and our results are consistent with the fact that high levels of $\mathrm{Co}, \mathrm{Cu}, \mathrm{Ni}$, and $\mathrm{Zn}$ are often associated with domestic discharges and industrial activities such as the presence of harbors and marinas (Fichez et al., 2005; Harris et al., 2001).

While highlighting the opportunity for further research regarding the sources of contamination, our study provides critical baseline values for the vast region of French Polynesia, and for coral reef areas in general. Our results emphasize the necessity to minimize the levels of metal(loid)s discharged in the marine environment of the most populated Islands in French Polynesia, where levels of certain metal(loid)s already exceed sediment quality guidelines, potentially threatening the health of coral reef organisms. This need is critical, especially as local stressors such as metal(loid) pollution may reduce the capacity of coral reefs to face the unprecedented changes associated with global warming and ocean acidification. 


\section{Acknowledgments}

This work was funded by the French National Research Agency (R-ECOLOGS, ANR-10-PDOC0013). We thank S. Planes, C. Churlaud, and J. Carlot for their help in conceiving, analyzing and formatting the data presented in this study. We thank the Contrat de Projet Etat-Région and the Fonds Européen de Développement Régional for funding the ICPs of LIENSs laboratory, and the National Center of Scientific Research and the Ecole Pratique des Hautes Etudes for their support. The IAEA is grateful for the support provided to its Environment Laboratories by the Government of the Principality of Monaco. The Institut Universitaire de France is acknowledged for its support to P.B. as a Senior Member.

\section{References}

Barletta, M., Lima, A.R.A., Costa, M.F., 2019. Distribution, sources and consequences of nutrients, persistent organic pollutants, metals and microplastics in South American estuaries. Sci. Total Environ. 651, 1199-1218.

Bastidas, C., Bone, D., Garcia, E.M., 1999. Sedimentation rates and metal content of sediments in a Venezuelan coral reef. Mar. Pollut. Bull. 38, 16-24.

Bolker, B.M., Brooks, M.E., Clark, C.J., Geange, S.W., Poulsen, J.R., Stevens, M.H.H., White, J.S.S., 2009. Generalized linear mixed models: a practical guide for ecology and evolution. Trends Ecol. Evol. 24, 127-35.

Bowen, H.J.M., 1979. Environmental Chemistry of the Elements, Academic Press, New York.

Buchman, M.F., 2008. NOAA Screening Quick Reference Tables, NOAA OR\&R Report 08-1, Seattle WA, Office of Response and Restoriation Division, National Oceanic and 
Atmospheric Administration.

Chapman, P.M., McDonald, B.G., Kickham, P.E., McKinnon, S., 2006. Global geographic differences in marine metals toxicity. Mar. Pollut. Bull. 52, 1081-1084.

Chevalier, J.P., 1973. Geomorphology and geology of coral reefs in French Polynesia, in: Biology \& Geology of Coral Reefs. pp. 113-141.

Coynel, A., Gorse, L., Curti, C., Schafer, J., Grosbois, C., Morelli, G., Ducassou, E., Blanc, G., Maillet, G.M., Mojtahid, M., 2016. Spatial distribution of trace elements in the surface sediments of a major European estuary (Loire Estuary, France): Source identification and evaluation of anthropogenic contribution. J. Sea Res. 118, 77-91.

de Souza Machado, A.A., Spencer, K., Kloas, W., Toffolon, M., Zarfl, C., 2016. Metal fate and effects in estuaries: A review and conceptual model for better understanding of toxicity. Sci. Total Environ. 541, 268-281.

Denton, G.R.W., Bearden, B.G., Concepcion, L.P., Wood, H.R., Morrison, R.J., 2006. Contaminant assessment of surface sediments from Tanapag Lagoon, Saipan, Commonwealth of the Northern Mariana Islands. Mar. Pollut. Bull. 52, 696-718.

Denton, G.R.W., Concepcion, L.P., Wood, H.R., Morrison, R.J., 2005. Trace metals in sediments of four harbours in Guam. Mar. Pollut. Bull. 50, 1121-1145.

Denton, G.R.W., Morrison, R.J., 2009. The impact of a rudimentary landfill on the trace metal status of Pago Bay, Guam. Mar. Pollut. Bull. 58, 150-162.

Fey, P., Bustamante, P., Bosserelle, P., Espiau, B., Malau, A., Mercader, M., Wafo, E., Letourneur, Y., 2019. Does trophic level drive organic and metallic contamination in coral reef organisms? Sci. Total Environ. 667, 208-221.

Fichez, R., Harris, P.A., Fernandez, J.M., Chevillon, C., Badie, C., 2005. Sediment records of past 
anthropogenic environmental changes in a barrier reef lagoon (Papeete, Tahiti, French Polynesia). Mar. Pollut. Bull. 50, 583-608.

Gibbs, R.J., Guerra, C., 1997. Metals of the bottom muds in Belize City Harbor, Belize. Environ. Pollut. 98, 135-138.

Gissi, F., Stauber, J.L., Binet, M.T., Golding, L.A., Adams, M.S., Schlekat, C.E., Garman, E.R., Jolley, D.F., 2016. A review of nickel toxicity to marine and estuarine tropical biota with particular reference to the South East Asian and Melanesian region. Environ. Pollut. 218, $1308-1323$.

Guzmán, H.M., Jiménez, C.E., 1992. Contamination of coral reefs by heavy metals along the Caribbean coast of Central America (Costa Rica and Panama). Mar. Pollut. Bull. 24, 554561.

Halpern, B.S., Walbridge, S., Selkoe, K.A., Kappel, C. V., Micheli, F., D’Agrosa, C., Bruno, J.F., Casey, K.S., Ebert, C., Fox, H.E., Fujita, R., Heinemann, D., Lenihan, H.S., Madin, E.M.P., Perry, M.T., Selig, E.R., Spalding, M., Steneck, R., Watson, R., 2008. A global map of human impact on marine ecosystems. Science 319, 948-952.

Harris, P., Fichez, R., Fernandez, J., Golterman, H., Badie, C., 2001. Using geochronology to reconstruct the evolution of particulate phosphorus inputs during the past century in the Papeete Lagoon (French Polynesia). Oceanol. Acta 24, 1-10.

Haynes, D., Johnson, J.E., 2000. Organochlorine, Heavy Metal and Polyaromatic Hydrocarbon Pollutant Concentrations in the Great Barrier Reef (Australia) Environment: a Review. Mar. Pollut. Bull. 41, 267-278.

Hédouin, L., Bustamante, P., Churlaud, C., Pringault, O., Fichez, R., Warnau, M., 2009a. Trends in concentrations of selected metalloid and metals in two bivalves from the coral reefs in the 
SW lagoon of New Caledonia. Ecotoxicol. Environ. Saf. 72, 372-381.

Hédouin, L., Metian, M., Gates, R.D., 2011a. Ecotoxicological approach for assessing the contamination of a Hawaiian coral reef ecosystem (Honolua Bay, Maui) by metals and a metalloid. Mar. Environ. Res. 71, 149-161.

Hédouin, L., Pringault, O., Bustamante, P., Fichez, R., Warnau, M., 2011b. Validation of two tropical marine bivalves as bioindicators of mining contamination in the New Caledonia lagoon: Field transplantation experiments. Water Res. 45, 483-496.

Hédouin, L., Reichelt-Brushett, A.J., Gates, R.D., 2009b. Assessment of metals and a metalloid in sediments from Hawaiian coral reef ecosystems. Mar. Pollut. Bull. 58, 1739-1765.

Insee/Ispf, 2017. Le recensement de la population en Polynésie française en 2017.

Kadhum, S.A., Ishak, M.Y., Zulkifli, S.Z., 2015. Evaluation and assessment of baseline metal contamination in surface sediments from the Bernam River, Malaysia. Environ. Sci. Pollut. Res. 23, 6312-6321.

Kaiser, H.F., 1960. The application of electronic computers to factor analysis. Educ. Psychol. Meas. 20, 141-151.

Long, E.R., Macdonald, D.D., Smith, S.L., Calder, F.D., 1995. Incidence of Adverse Biological Effects Within Ranges of Chemical Concentrations in Marine and Estuarine Sediments. Environ. Heal. 19, 81-97.

Metian, M., Bustamante, P., Hédouin, L., Warnau, M., 2008. Accumulation of nine metals and one metalloid in the tropical scallop Comptopallium radula from coral reefs in New Caledonia. Environ. Pollut. 152, 543-552.

Morrison, R.J., Narayan, S.P., Gangaiya, P., 2001. Trace element studies in Laucala Bay, Suva, Fiji. Mar. Pollut. Bull. 42, 397-404. 
Morrison, R.J., Peshut, P.J., Lasorsa, B.K., 2010. Elemental composition and mineralogical characteristics of coastal marine sediments of Tutuila, American Samoa. Mar. Pollut. Bull. $60,925-30$.

Negri, A.P., Flores, F., Röthig, T., Uthicke, S., 2011. Herbicides increase the vulnerability of corals to rising sea surface temperature. Limnol. Oceanogr. 56, 471-485.

Negri, A.P., Hoogenboom, M.O., 2011. Water contamination reduces the tolerance of coral larvae to thermal stress. PLoS One 6, e19703.

Noyes, P.D., McElwee, M.K., Miller, H.D., Clark, B.W., Van Tiem, L.A., Walcott, K.C., Erwin, K.N., Levin, E.D., 2009. The toxicology of climate change: Environmental contaminants in a warming world. Environ. Int. 35, 971-986.

ORSTOM, 1993. Office de la Recherche Scientifique et Technique Outre-Mer. Atlas de la Polynésie Française. Paris : Éditions de l’ORSTOM.

Reichelt, A.J., Jones, G.B., 1994. Trace-metals as tracers of dredging activity in Cleveland Bay Field and laboratory studies. Aust. J. Mar. Freshw. Res. 45, 1237-1257.

Roche, H.R., Salvat, B.S., Ramade, F.R., 2011. Assessment of the pesticide pollution of coral reef communities from French Polynesia. Rev. d'Ecologie 66, 3-10.

Rodriguez-Barroso, M.R., Garcia-Morales, J.L., Coello Oviedo, M.D., Quiroga Alonso, J.M., 2010. An assessment of heavy metal contamination in surface sediment using statistical analysis. Environ. Monit. Assess. 163, 489-501.

Stoeppler, M., Nürnberg, H.W., 1979. Comparative studies on trace metal levels in marine biota II. Trace metals in krill, krill products, and fish from the antarctic scotia sea. Ecotoxicol. Environ. Saf. 3, 335-351.

Thiault, L., Marshall, P., Gelcich, S., Collin, A., Chlous, F., Claudet, J., 2018. Space and time 
matter in social-ecological vulnerability assessments. Mar. Policy 88, 213-221.

Tomlinson, D.L., Wilson, J.G., Harris, C.R., Jeffrey, D.W., 1980. Problems in the assessment of heavy-metal levels in estuaries and the formation of a pollution index. Helgoländer Meeresunters 33, 566-575.

van Dam, J.W., Negri, A.P., Uthicke, S., Mueller, J.F., 2011. Chemical Pollution on Coral Reefs: Exposure and Ecological Effects, in: Ecological Impacts of Toxic Chemicals. pp. 187-211.

Yongming, H., Peixuan, D., Junji, C., Posmentier, E.S., 2006. Multivariate Analysis of Heavy Metal Contamination in Urban Dusts of Multivariate analysis of heavy metal contamination in urban dusts of Xi' an, Central China. Sci. Total Environ. 355, 176-186. 


\section{Supplementary material}

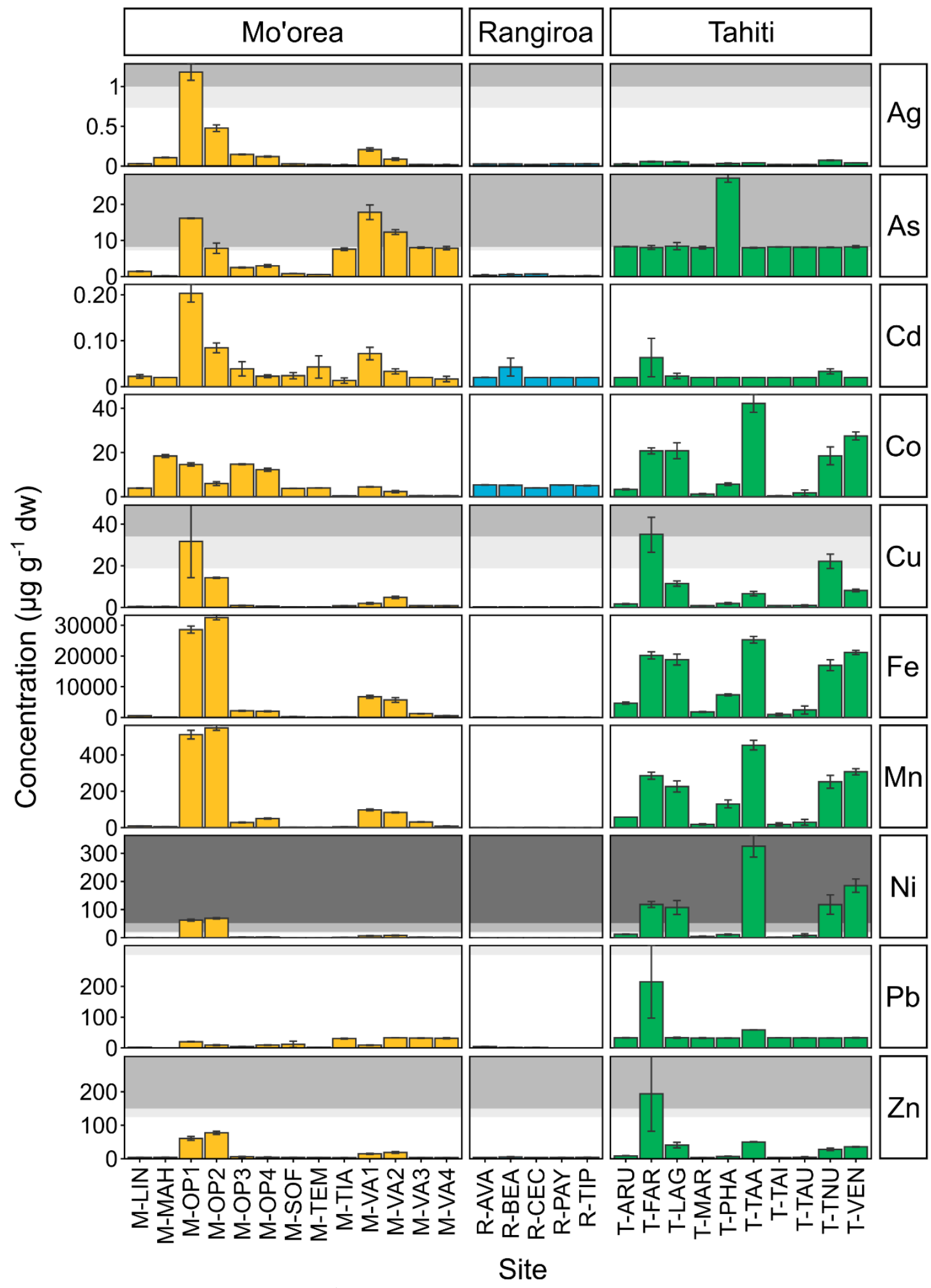

Figure S1. Concentrations ( $\mu \mathrm{g} \mathrm{g}^{-1} \mathrm{dw}$ ) of $\mathrm{Ag}, \mathrm{As}, \mathrm{Cd}, \mathrm{Co}, \mathrm{Cu}, \mathrm{Fe}, \mathrm{Mn}, \mathrm{Ni}, \mathrm{Pb}$ and $\mathrm{Zn}$ in superficial sediments from coral reefs of French Polynesia. Sites are indicated by the initial of the island, followed by the site name as in Fig. 1. Each bar indicates the mean $(n=3)$ and error-bars indicate sd. Gray backgrounds indicate sediment quality guidelines: Threshold Effect Level (TEL, light gray), Effect Range Low (ERL, gray) and Effect Range Median (ERM, dark gray). 

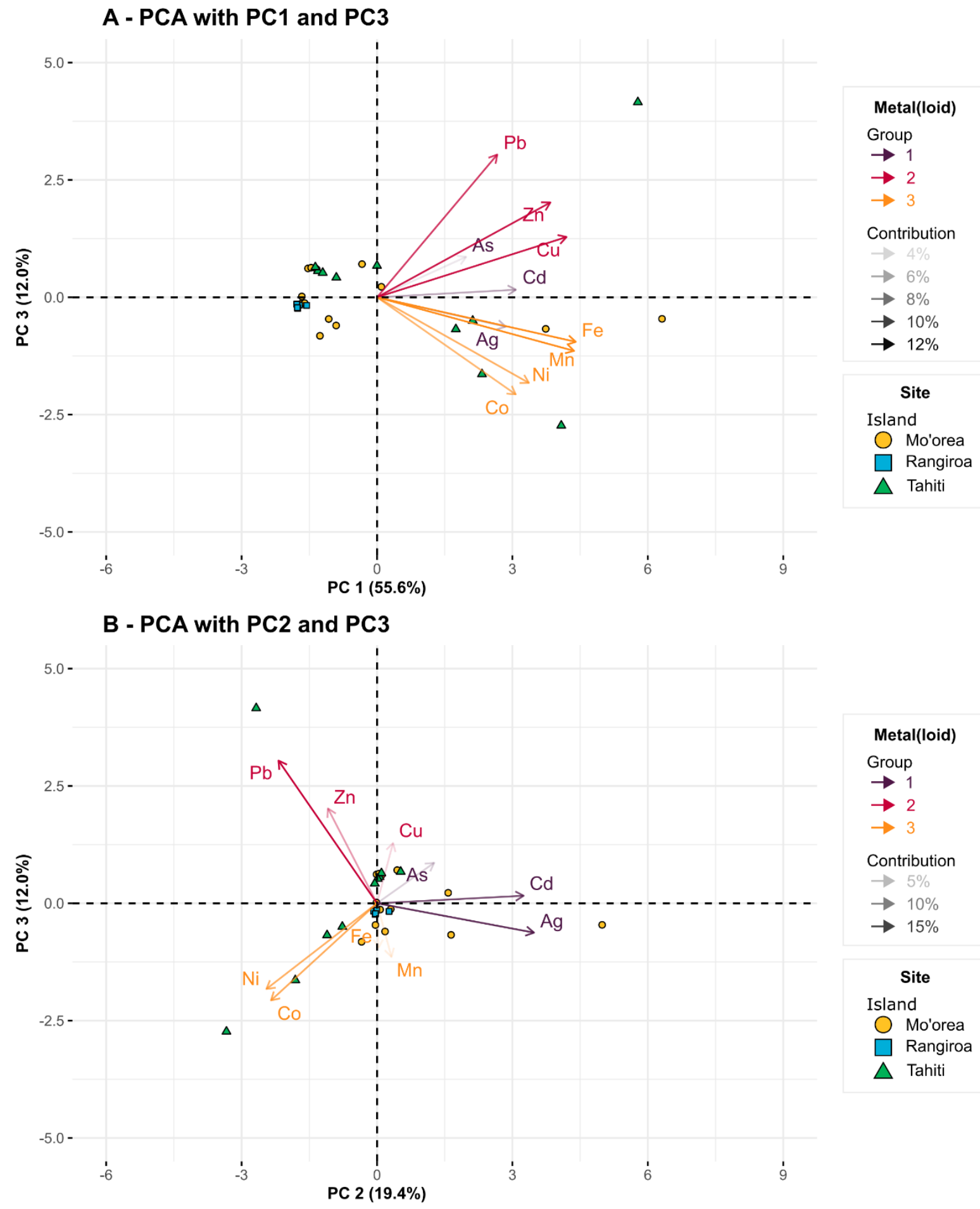

Figure S2. Site and metal(loid) grouping based on the levels measured in the sediment. A: Principal Component Analysis (PCA) with PC1 and PC3 of sites (as individuals) and metal(loid)s (as variables) according to the metal(loid) levels at the 28 sites from Mo'orea, Rangiroa and Tahiti. B: Principal Component Analysis (PCA) with PC2 and PC3 of sites (as individuals) and metal(loid)s (as variables) according to the metal(loid) levels at the 28 sites from Mo'orea, Rangiroa and Tahiti. The three main clusters of metal(loid)s have been added to each PCA. 
Table S1. Site location, code and description. Sites are indicated by the initial of the island, followed by the site name as in Fig. 1.

\begin{tabular}{|c|c|c|}
\hline Island & Site & Description \\
\hline Mo'orea & M-LIN & Linareva. Fringing reef on the West coast, far from any anthropogenic activities. \\
\hline Mo'orea & M-MAH & Mahana. Fringing reef on the north coast, relatively far from any anthropogenic activities. \\
\hline Mo'orea & M-OP1 & $\begin{array}{l}\text { Opunohu bay } 1 \text {. No coral-reef structure, east coast of Opunohu bay, very close to the river mouth } \\
\text { Opunohu watershed includes } 1500 \text { ha devoted to agricultural practices and approximately } 55 \text { farmers. }\end{array}$ \\
\hline Mo'orea & M-OP2 & $\begin{array}{l}\text { Opunohu bay 2. No coral-reef structure, east coast of Opunohu bay, further away from the river mouth } \\
\text { than M-OP1. }\end{array}$ \\
\hline Mo'orea & M-OP3 & Opunohu bay 3. Fringing reef on the east coast of Opunohu bay, closest coral reefs from the river mouth \\
\hline Mo'orea & M-OP4 & $\begin{array}{l}\text { Opunohu bay } 4 \text {. Fringing reef on the east coast of Opunohu Bay, further away from the river mouth than } \\
\text { M-OP3. }\end{array}$ \\
\hline Mo'orea & M-SOF & $\begin{array}{l}\text { Sofitel. Fringing reef on the northeast coast, close to Tema'e marine protected area, in front of a hote } \\
\text { resort. }\end{array}$ \\
\hline Mo'orea & M-TEM & Tema'e. Barrier reef on the northeast coast located in a marine protected area. \\
\hline Mo'orea & M-TIA & $\begin{array}{l}\text { Tiahura. Fringing reef on the northwest coast located in a marine protected area, which is subjected to } \\
\text { intense touristic activities (hotels and recreational and touristic boats). }\end{array}$ \\
\hline Mo'orea & M-VA1 & $\begin{array}{l}\text { Vaiare bay 1. Fringing reef located on the east coast, very close to the ferry pier in an area of intense boa } \\
\text { traffic and south to Vaiare river mouth. Vaiare bay also hosts several shops and businesses. }\end{array}$ \\
\hline Mo'orea & M-VA2 & $\begin{array}{l}\text { Vaiare bay } 2 \text {. Fringing reef located on the east coast, very close to the ferry pier in an area of intense boa } \\
\text { traffic and north to Vaiare river mouth. }\end{array}$ \\
\hline Mo'orea & M-VA3 & $\begin{array}{l}\text { Vaiare bay } 3 \text {. Fringing reef with clear water and high waves energy located further away from Vaiare river } \\
\text { mouth and harbor. }\end{array}$ \\
\hline Mo'orea & M-VA4 & Vaiare bay 4. Fringing reef on the east coast of Mo'orea localed just outside the Vaiare bay. \\
\hline Rangiroa & R-AVA & Avatoru pass. Fringing reef with clear water and intense current located close by the Avatoru pass. \\
\hline Rangiroa & R-BEA & $\begin{array}{l}\text { Public beach. Fringing reef located at the official Rangiroa public beach, inside the lagoon, on the north } \\
\text { part of Rangiroa. }\end{array}$ \\
\hline Rangiroa & R-CEC & Cécile family hotel. Fringing reef located inside the lagoon, on the north part of Rangiroa. \\
\hline Rangiroa & R-PAY & $\begin{array}{l}\text { Payo islet. Fringing reef located close to the Payo islet, at } 10 \mathrm{~km} \text { south from Avatoru pass, inside the } \\
\text { lagoon. }\end{array}$ \\
\hline Rangiroa & R-TIP & $\begin{array}{l}\text { Tiputa dock. Fringing reef with high current and clear water, located at the dock of Tiputa pass, where } \\
\text { boat traffic ensures the daily transfer between Rangiroa islets and the diving activities. }\end{array}$ \\
\hline Tahiti & T-ARU & $\begin{array}{l}\text { Arue marina. Fringing reef in a marina (boat capacity: 160) located } 4 \mathrm{~km} \text { north from Papeete, subjected to } \\
\text { discharges by boats and other human activities. }\end{array}$ \\
\hline Tahiti & T-FAR & $\begin{array}{l}\text { Fare ute marina. Fringing reef in the center of Papeete, in a marina with a boat capacity of } 140 \text {. Area } \\
\text { subjected to heavy discharge from boats, nearby industries, Papeete harbor and other human activities. }\end{array}$ \\
\hline Tahiti & T-LAG & $\begin{array}{l}\text { Lagoonarium. Fringing reef located } 10 \mathrm{~km} \text { south from Papeete, on the west coast at Punaauia, a heavily } \\
\text { inhabited area with numerous goods and services establishments. }\end{array}$ \\
\hline Tahiti & T-MAR & $\begin{array}{l}\text { Maraa grotto. Fringing reef located } 28 \mathrm{~km} \text { south from Papeete, on the west coast just south of Pae'a city } \\
\text { in a low inhabited area. }\end{array}$ \\
\hline Tahiti & T-PHA & $\begin{array}{l}\text { Phaeton bay. Fringing reef located on the southwest coast, at the isthmus near Taravao city. Area subjected } \\
\text { to many river discharges (Vaiperetei, Vaitarua, Vaitaare, Oopu, Vaipue, Fataaiti) resulting in high turbidity } \\
\text { and sedimentation. A marina (boat capacity: 50) and a commercial center are present nearby. }\end{array}$ \\
\hline Tahiti & T-TAA & $\begin{array}{l}\text { Taapuna. Fringing reef located at } 10 \mathrm{~km} \text { southwest from Papeete, close to a black sandy beach and in an } \\
\text { urbanized area (Puna'auia) in the Atiue district. }\end{array}$ \\
\hline Tahiti & T-TAI & $\begin{array}{l}\text { Taina marina. Fringing reef located at } 5 \mathrm{~km} \text { southwest from Papeete, in a marina (boat capacity: } 550 \text { ) } \\
\text { subjected to discharges from boats and other human activities. }\end{array}$ \\
\hline Tahiti & T-TAU & $\begin{array}{l}\text { Tautira bay. Fringing reef located at } 49 \mathrm{~km} \text { southeast from Papeete, on Tahiti iti, in an area subjected to } \\
\text { discharges from Tautira and Vaitepiha rivers, but with extremely low population and shop densities. }\end{array}$ \\
\hline Tahiti & T-TNU & $\begin{array}{l}\text { Tainu'u. Fringing reef located on the west coast, close by the Punaruu river and located in an } \\
\text { urbanized area (Puna'auia). }\end{array}$ \\
\hline Tahiti & T-VEN & $\begin{array}{l}\text { Venus point. Fringing reef located at the north cape, in Mahina city, } 10 \mathrm{~km} \text { north from Papeete, in a } \\
\text { moderately inhabited but highly touristic area (seaside). }\end{array}$ \\
\hline
\end{tabular}


Table S2. Percentage of recovery of Certified Reference Materials (DOLT-4, MESS-3 and TORT-2) from the NRCC. NA stands for Not Analyzed.

\begin{tabular}{cccc}
\hline Element & DOLT4 & MESS3 & TORT2 \\
\hline $\mathrm{Ag}$ & & & $\mathrm{NA}$ \\
$\mathrm{As}$ & 95 & 83 & 102 \\
$\mathrm{Cd}$ & 107 & 93 & 96 \\
$\mathrm{Co}$ & 95 & 88 & 99 \\
$\mathrm{Cu}$ & $\mathrm{NA}$ & 84 & 92 \\
$\mathrm{Fe}$ & 98 & 86 & 93 \\
$\mathrm{Mn}$ & 99 & $\mathrm{NA}$ & 92 \\
$\mathrm{Ni}$ & $\mathrm{NA}$ & 83 & 89 \\
$\mathrm{~Pb}$ & 91 & 80 & 84 \\
$\mathrm{Zn}$ & $\mathrm{NA}$ & 80 & 104 \\
\hline
\end{tabular}


Table S3. Eigenvalues and percentage of explained variance of the Principal Component Analysis (PCA) on the metal(loid) levels in the 28 sites of French Polynesia.

\begin{tabular}{cccc}
\hline PC & Eigenvalue & Explained variance (\%) & Cumulative explained variance (\%) \\
\hline & & & \\
1 & 5.556 & 55.561 & 55.561 \\
2 & 1.938 & 19.383 & 74.944 \\
3 & 1.199 & 11.993 & 86.937 \\
4 & 0.854 & 8.541 & 95.477 \\
5 & 0.239 & 2.394 & 97.871 \\
6 & 0.098 & 0.983 & 98.855 \\
7 & 0.071 & 0.714 & 99.569 \\
8 & 0.034 & 0.342 & 99.911 \\
9 & 0.005 & 0.055 & 99.966 \\
10 & 0.003 & 0.034 & 100.000 \\
\hline
\end{tabular}


Table S4. PCA loading factors.

\begin{tabular}{cccc}
\hline Element & PC1 & PC2 & PC3 \\
\hline & & & \\
$\mathrm{Ag}$ & 0.26 & 0.54 & -0.12 \\
$\mathrm{As}$ & 0.18 & 0.20 & 0.17 \\
$\mathrm{Cd}$ & 0.28 & 0.50 & 0.03 \\
$\mathrm{Co}$ & 0.28 & -0.36 & -0.41 \\
$\mathrm{Cu}$ & 0.38 & 0.05 & 0.25 \\
$\mathrm{Fe}$ & 0.40 & 0.01 & -0.19 \\
$\mathrm{Mn}$ & 0.40 & 0.05 & -0.22 \\
$\mathrm{Ni}$ & 0.31 & -0.38 & -0.36 \\
$\mathrm{~Pb}$ & 0.24 & -0.34 & 0.60 \\
$\mathrm{Zn}$ & 0.35 & -0.17 & 0.40 \\
& & & \\
\hline
\end{tabular}


Table S5. Metal(loid)s correlation analysis associated p-values. Values in bold indicate $\mathrm{P}$ values $<0.05$.

\begin{tabular}{|c|c|c|c|c|c|c|c|c|c|c|}
\hline & Ag & As & Cd & Co & $\mathrm{Cu}$ & $\mathbf{F e}$ & Mn & $\mathbf{N i}$ & $\mathbf{P b}$ & $\mathbf{Z n}$ \\
\hline \multirow[t]{10}{*}{ Ag } & & 0.009 & $<0.001$ & 0.524 & $<0.001$ & 0.001 & $<0.001$ & 0.654 & 0.726 & 0.1302 \\
\hline & As & & 0.082 & 0.857 & 0.103 & 0.031 & 0.030 & 0.370 & 0.191 & 0.321 \\
\hline & & Cd & & 0.564 & $<0.001$ & 0.001 & $<0.001$ & 0.630 & 0.663 & 0.022 \\
\hline & & & Co & & 0.014 & $<0.001$ & $<0.001$ & $<0.001$ & 0.076 & 0.012 \\
\hline & & & & $\mathrm{Cu}$ & & $<0.001$ & $<0.001$ & 0.009 & $<0.001$ & $<0.001$ \\
\hline & & & & & $\mathbf{F e}$ & & $<0.001$ & $<0.001$ & 0.045 & $<0.001$ \\
\hline & & & & & & Mn & & $<0.001$ & 0.085 & $<0.001$ \\
\hline & & & & & & & $\mathbf{N i}$ & & 0.026 & 0.005 \\
\hline & & & & & & & & $\mathbf{P b}$ & & $<0.001$ \\
\hline & & & & & & & & & $\mathrm{Zn}$ & \\
\hline
\end{tabular}




\section{Supplementary Text 1. Sediment quality guidelines.}

TEL represents the concentrations below which adverse effects rarely occur, ERL corresponds to concentrations above which negative effects are more common, and ERM corresponds to concentrations at or above which negative effects frequently occur. Of the metal(loid)s tested, no guidelines values are available for $\mathrm{Co}, \mathrm{Fe}$ and $\mathrm{Mn}$.

\section{Supplementary Text 2. Statistical analyses.}

A Gamma Generalised Linear Mixed-Effects Model (Bolker et al., 2009) was run to assess whether the site location influenced sediment contamination in metal(loid)s. PLI was used as the dependant variable and followed a gamma distribution. Replicate identity was included as a random factor to account for potential differences only due to technical issues. A top-down approach using Likelihood Ratio Tests and the Akaike Information Criterion (AIC) was used to assess the explanatory power of this model in comparison to the null model (Zuur et al., 2009). Using the $\{1 \mathrm{me} 4\}$ package (Bates et al., 2015) in $R$ version 3.5.3 (R Core Team, 2020), the following model was therefore ran: model = glmer(PLI Site + (1|Replicate), family = Gamma(link = log $)$, data $).$ Following this, a Tukey’s posthoc test was ran using the glht function in the \{multcomp $\}$ package (Hothorn et al., 2008): posthoc $=\operatorname{glht}($ model linfct $=\operatorname{mcp}($ Site $=$ "Tukey" $)))$. The level of significance for statistical analyses was set at $\alpha=0.05$. Detailed output of the posthoc test presented in Fig. $4: \mathrm{a}<\mathrm{b}(\mathrm{p}<0.001)$; $\mathrm{b}<\mathrm{c}(\mathrm{p}<0.01) ; \mathrm{c}<\mathrm{d}(\mathrm{p}<0.001) ; \mathrm{d}<\mathrm{e}(\mathrm{p}<0.01) ; \mathrm{e}<\mathrm{f}(\mathrm{p}<0.001) ; \mathrm{f}<\mathrm{g}(\mathrm{p}<0.001) ; \mathrm{g}<\mathrm{h}$ $(\mathrm{p}<0.05) ; \mathrm{h}<\mathrm{i}(\mathrm{p}<0.01) ; \mathrm{i}<\mathrm{j}(\mathrm{p}<0.01) ; \mathrm{j}<\mathrm{k}(\mathrm{p}<0.001) ; \mathrm{k}<1(\mathrm{p}<0.05) ; 1<\mathrm{m}(\mathrm{p}<0.001)$. 


\section{Supplementary References}

Bates, D., Mächler, M., Bolker, B.M., Walker, S.C., 2015. Fitting Linear Mixed-Effects Models Using lme4. J. Stat. Softw. 67, 1-48.

Bolker, B.M., Brooks, M.E., Clark, C.J., Geange, S.W., Poulsen, J.R., Stevens, M.H.H., White, J.S.S., 2009. Generalized linear mixed models: a practical guide for ecology and evolution. Trends Ecol. Evol. 24, 127-35.

Hothorn, T., Bretz, F., Westfall, P., 2008. Simultaneous Inference in General Parametric Models. Biometric J. 50, 346-363.

R Core Team, 2020. R: A language and environment for statistical computing. R Foundation for Statistical Computing, Vienna, Austria. URL http://www.R-project.org/.

Zuur, A., Leno, E.N., Walker, N., Saveliev, A.A., Smith, G.M., 2009. Mixed Effects Models and Extensions in Ecology with R. New York, NY: Springer. 